研 究

\title{
マグネシウムと低融点金属酸化物とのメカニカルアロイングと固相反応
}

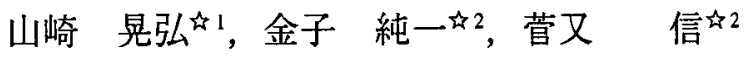 \\ 41 日本大学大学院生産工学研究科機械工学尃攻, 于 275-8575 習志野市泉町 1-2-1. \\ 42 日本大学生産工学部機械工学科, $=275-8575$ 習志野市泉町 1-2-1。
}

\section{Solid State Reaction in Mechanically Alloyed Magnesium with Addition of Low-Melting-Metal Oxides}

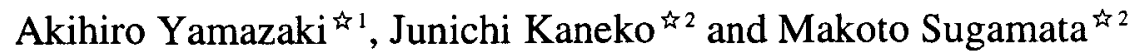 \\ if 1 Graduate School of Industrial Technology, Nihon University, 1-2-1 Izumi-cho Narashino 275-8575. \\ \&2 Department of Mechanical Engineering, College of Industrial Technology, Nihon University, 1-2-1 Izumi-cho Narashino $275-8575$.
}

Received February 19, 2001

\begin{abstract}
SYNOPSIS
Pure magnesium powders were mechanically alloyed with addition powders of low-melting-metal oxides $\left(\mathrm{SnO}_{2}\right.$, $\mathrm{PbO}$ and $\mathrm{Sb}_{2} \mathrm{O}_{3}$ ) by using a planetary ball mill under an $\mathrm{Ar}$ atmosphere. After mechanical alloying, the powders were consolidated to the $\mathrm{P} / \mathrm{M}$ materials by vacuum hot pressing. Solid state reaction in the mechanically alloyed powders and the P/M materials was studied by XRD and DSC. In these systems, the solid state reaction started to occur during MA processing between $\mathrm{Mg}$ and low-melting-metal oxides. The added low-melting metal oxides decomposed and formation of $\mathrm{MgO}$ and intermetallic compounds $\left(\mathrm{Mg}_{2} \mathrm{Sn}, \mathrm{Mg}_{2} \mathrm{~Pb}, \mathrm{Mg}_{3} \mathrm{Sb}_{2}\right)$ occurred. Such solid state reaction further progressed during hot-pressing and subsequent heat treatment. Microstructures were studied by TEM and mechanical strength was discussed by hardness values for both MA powders and P/M materials.
\end{abstract}

KEY WORDS

mechanical alloying, magnesium, low-melting-metal oxide, powder metallurgy, solid state reaction

\section{1 緒言}

$\mathrm{Mg}$ 合金は, 実用構造用金属材料の中で最も低密度で内部隇 衰能が高いことから携带用機器に非常に有利な材料であるが,

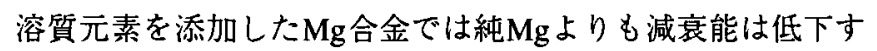
る.しかし，固溶限の小さい元素 $(\mathrm{Sb}, \mathrm{Si}$ など ) を添加する場 合は第 2 相が粒界に析出してマトリックスのマグネシウムの 純度は純 $\mathrm{Mg}$ とほとんど差が無いので, 隇衰能の低下は極力 抑えられる". 一方, ダイカスト法などの溶解鋳造法で多く用 いられているAZ91 合金も含めて Mg合金の問題点は耐熱性で ある。これを改善するには高温でも安定なセラミックス $\left(\mathrm{MgO}^{2)}\right.$ など) や金属間化合物 $\left(\mathrm{Mg}_{2} \mathrm{Sn}^{3)}, \mathrm{Mg}_{2} \mathrm{Si}^{4)}\right.$ など $)$ を $\mathrm{Mg}$ マトリッ クス中に微細分散させることで可能であると思われ， $\mathrm{Mg}$ と $\mathrm{Sb}$ との金属間化合物 $\mathrm{Mg}_{3} \mathrm{Sb}_{2}$ の分散によりクリープ強度が増加 したとの報告らがある.しかし，これらを材料創製プロセスと 関連づけて調べた報告は少ないのが現状である．

そこで, 粉末治金法の一種であるメカニカルアロイング(以 下MA)法に着目した. MA 法を適用すれば, 溶解過程を伴わ ずに合金化が達成され $\mathrm{SF}_{6}$ ガスを使用する必要もないため環
境に優しく, 密度差の大きい元素や融点差の大きい元素の合 金化も可能である。また，大きなひずみエネルギーを粉末に 付与し, 比較的低い温度での拡散を促進することで, 結晶粒 の微細化, 微細均一な粒子の分散などによる材料の高強度化 が達成できる.加えて，MA中およびその後の加熱中に起きる 固相反応によって添加物の分解之反応生成物の微細分散を図 ることも可能である. $\mathrm{Mg}$ 粉末と $\mathrm{SiO}_{2}$ 粉末の組み合わせで $\mathrm{MA}$ 処理した材料においては, $\mathrm{Mg}$ 中で $\mathrm{SiO}_{2}$ が分解して微細な $\mathrm{MgO}$ および $\mathrm{Mg}_{2} \mathrm{Si}$ 粒子が生成することを報告した4). 本研究 では $\mathrm{Sn}, \mathrm{Pb}, \mathrm{Sb}$ の 3 種類の低融点金属の酸化物粉末 $\left(\mathrm{SnO}_{2}, \mathrm{PbO}\right.$, $\left.\mathrm{Sb}_{2} \mathrm{O}_{3}\right)$ を $\mathrm{Mg}$ 粉末に添加して $\mathrm{MA}$ 処理を行った。これにより $\mathrm{Mg}$ と低融点金属との合金化を図ることを試み，MAによる反 応過程および反応に伴う機械的性質の変化を調べた。

\section{2 試料及び実験方法}

原料粉末として純 $\mathrm{Mg}$ 粉末 (約 $50 \mu \mathrm{m}$ ) と低融点金属の酸化物 粉末 $\left(\mathrm{SnO}_{2}, \mathrm{PbO}, \mathrm{Sb}_{2} \mathrm{O}_{3} ; 2 \mu \mathrm{m}\right.$ under: 純度 $\left.99.9 \%\right)$ を用いた。試 料の配合組成を Table 1に示す，配合組成は，低融点金属が $3 a t \%$ 
となるように決定し精密天秤を用いて秤量した。この混合粉 末について遊星型ボールミル (Fritsch, P-5)により, MA 処理を 行った. MA 処理には内容量 $500 \mathrm{ml}$ のステンレス鋼製容器と 直径 $10 \mathrm{~mm}$ のステンレス鋼製ボールを用いた。装填量は混合 粉末 $25 \mathrm{~g}$ とし，ボールと粉末の重量比が約 16 となるように ボール 100 個 (402g) とミリング助棛としてのステアリン酸 $\left[\mathrm{CH}_{3}\left(\mathrm{CH}_{2}\right)_{10} \mathrm{CO}_{2} \mathrm{H}\right] 0.6 \mathrm{~g}$ とともに Ar ガスに置換したグローブ ボックス中でミリング容器に封入した. MAを108ks行った粉 末は原料粉末装入後, $108 \mathrm{ks}$ まで連続運転し得られた粉末であ るが, MAが54.0ksまでの粉末は適時, MA 処理を止め, MA 粉末を少量取り出し，その後続けて運転し作製した。

試料の作製工程の模式図を Fig.1 に示す.MA 処理条件は, 容器の公転速度 $300 \mathrm{rpm}$ で行い，作製した MA 粉末は Ar ガス 雾囲気中で取り出した。 ホットプレス(以下HP)体の作製には MAを $108 \mathrm{ks}$ 行った粉末を用いた. MA 粉末を AZ31Mg 合金製 容器に封入し，これを真空度 $1.33 \times 10^{-3} \mathrm{~Pa}$ の下で $3.6 \mathrm{ks}$ かけて $673 \mathrm{~K}$ まで昇温し，100 MPaの加圧を $3.6 \mathrm{ks}$ 行うことで HP体を 作製した。

Table 1 Nominal composition of the test materials.

\begin{tabular}{|c|c|c|}
\hline matrix & $\begin{array}{c}\text { additive } \\
\text { (mass\%) }\end{array}$ & $\begin{array}{c}\text { composition } \\
\text { (at\%) }\end{array}$ \\
\hline \multirow{4}{*}{$\mathrm{Mg}$} & $17.0 \% \mathrm{SnO}_{2}$ & $\mathrm{Mg}-3 \% \mathrm{Sn}-6 \% \mathrm{O}$ \\
\cline { 2 - 3 } & $22.6 \% \mathrm{PbO}$ & $\mathrm{Mg}-3 \% \mathrm{~Pb}-3 \% \mathrm{O}$ \\
\cline { 2 - 3 } & $16.0 \% \mathrm{Sb}_{2} \mathrm{O}_{3}$ & $\mathrm{Mg}-3 \% \mathrm{Sb}-4.5 \% \mathrm{O}$ \\
\hline
\end{tabular}

$\mathrm{MA}$ 粉末と HP 体における構成相の変化を X 線回折 (XRD: Shimadzu XD-610)扔よび示差走查熱分析(DSC: Shimadzu DSC50)により調べた，XRDは CuK $\alpha$ 線を用いて，回折速度 $16.7 \times$ $10^{-3} \mathrm{deg} / \mathrm{s}$ で行い, DSC は昇温速度 $0.167 \mathrm{~K} / \mathrm{s}$ で室温から $873 \mathrm{~K}$ まで行った。また組織観察は透過型電子顕微鏡 (TEM: JEOL JEM-2010)を用いて行った. TEM 用試料は硝酸 $5 \mathrm{vol} \%$-エ夕 ノール溶液を用いて電解双ジェット研磨により作製し，これ を加速電圧 $200 \mathrm{kV}$ で観察した．また，MA 粉末に対してマイ クロビッカース硬度計を, HP体に対してビッカース硬度計を 用い，20ヶ所の硬さの平均値を求めた。

\section{3 実験結果および考察}

3.1 MA 中およびその後の加熱による固相反応

Fig.2に $\mathrm{Mg}-\mathrm{SnO}_{2}$ 系で固相反応が起こる過程をX線回折によ り調べた結果を示す，Fig.2中では出発原料である $\mathrm{Mg}$ および $\mathrm{SnO}_{2}$ からの回折線も合わせて示す. $\mathrm{SnO}_{2}$ からの回折線がミリ ング時間の増加とともに弱くなり，MAを $28.8 \mathrm{ks}$ 行った段階 で完全に消失した。一方，MAを $1.8 \mathrm{ks}$ 行った段階で早くも

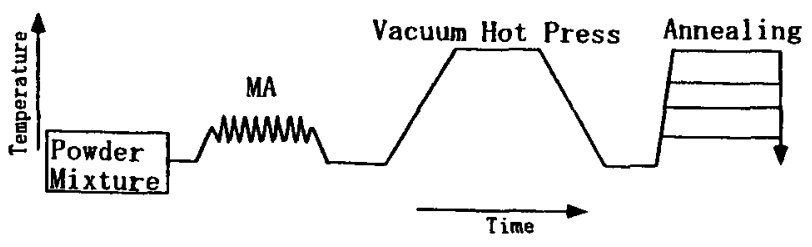

Fig.1 Illustration of thermal and mechanical processes for the test materials.

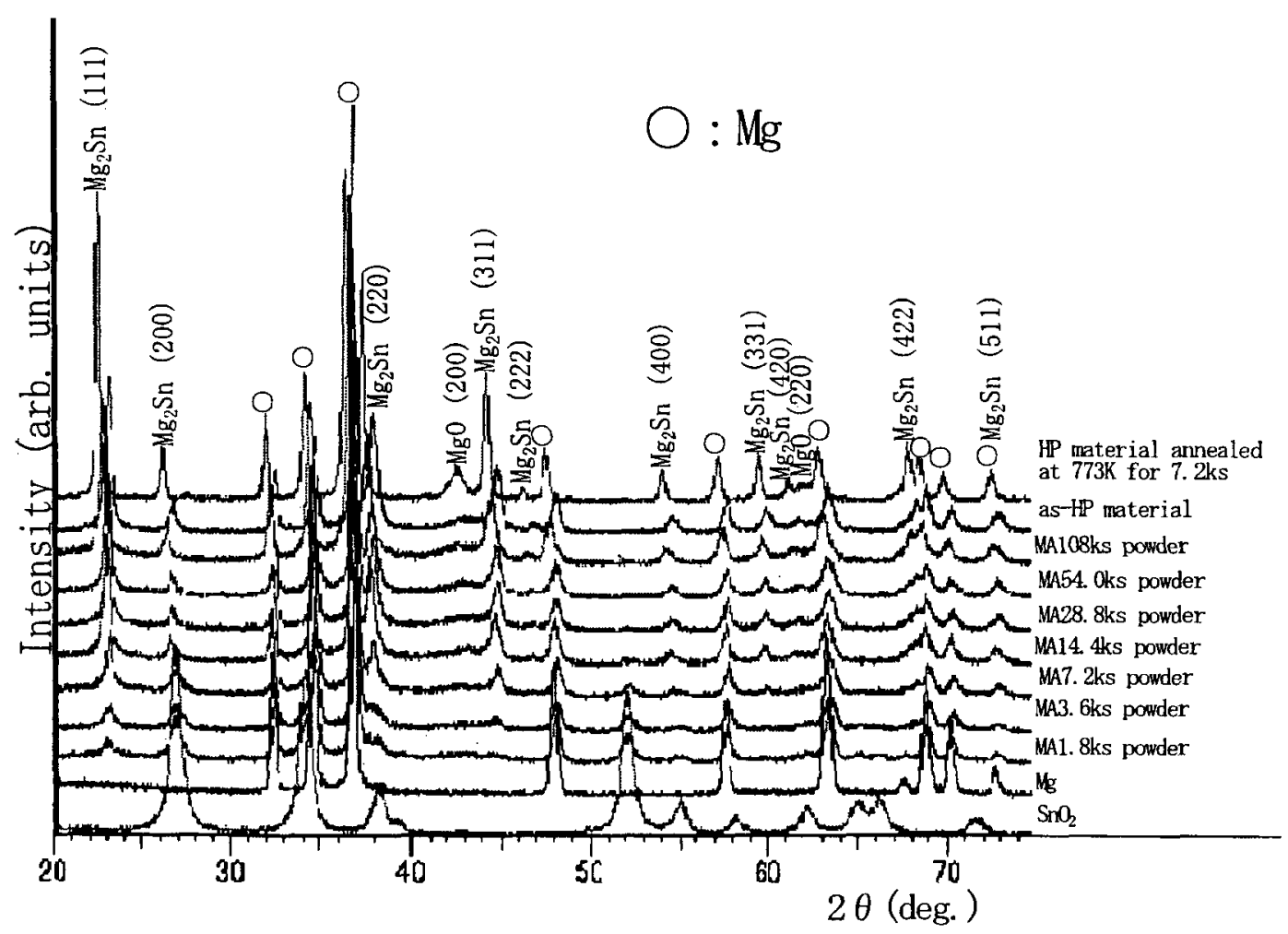

Fig.2 X-ray diffraction patterns of MA powders and $\mathrm{HP}$ material of $\mathrm{Mg}-\mathrm{SnO}_{2}$ system. 
$\mathrm{Mg}_{2} \mathrm{Sn}$ からの回折線を検出できるようになった，更なる MA 時間の増加につれ， $\mathrm{Mg}_{2} \mathrm{Sn}$ の回折線強度が増加した。加えて $\mathrm{MgO}$ の回折線も MA中に検出できるようになり，HP体を $773 \mathrm{~K}$ で7.2ks加熱した試料ではMgOからの回折線が明暸になった. また，ミリング時間の増加につれて $\mathrm{Mg}$ のピークがブロード になった。

$\mathrm{Mg}-\mathrm{PbO}$ 系および $\mathrm{Mg}-\mathrm{Sb}_{2} \mathrm{O}_{3}$ 系についての X 線回折結果を
Fig.3 およびFig.4に示す，Mg-PbO系では MAを $1.8 \mathrm{ks}$ 行った 段階で $\mathrm{PbO}$ からの回折線が消失し, $\mathrm{Mg}_{2} \mathrm{~Pb}$ からの回折線を検 出できるようになり，ミリング時間の増加により $\mathrm{Mg}_{2} \mathrm{~Pb} か ら$ の回折線強度も増加した，HP体を加熱した試料においては

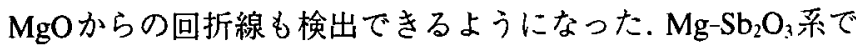
はMAを $1.8 \mathrm{ks}$ 行った段階で $\mathrm{Sb}_{2} \mathrm{O}_{3}$ からの回折線が完全に消失 したが, $\mathrm{Mg}_{3} \mathrm{Sb}_{2}$ からの回折線を MA 粉末では認めることがで

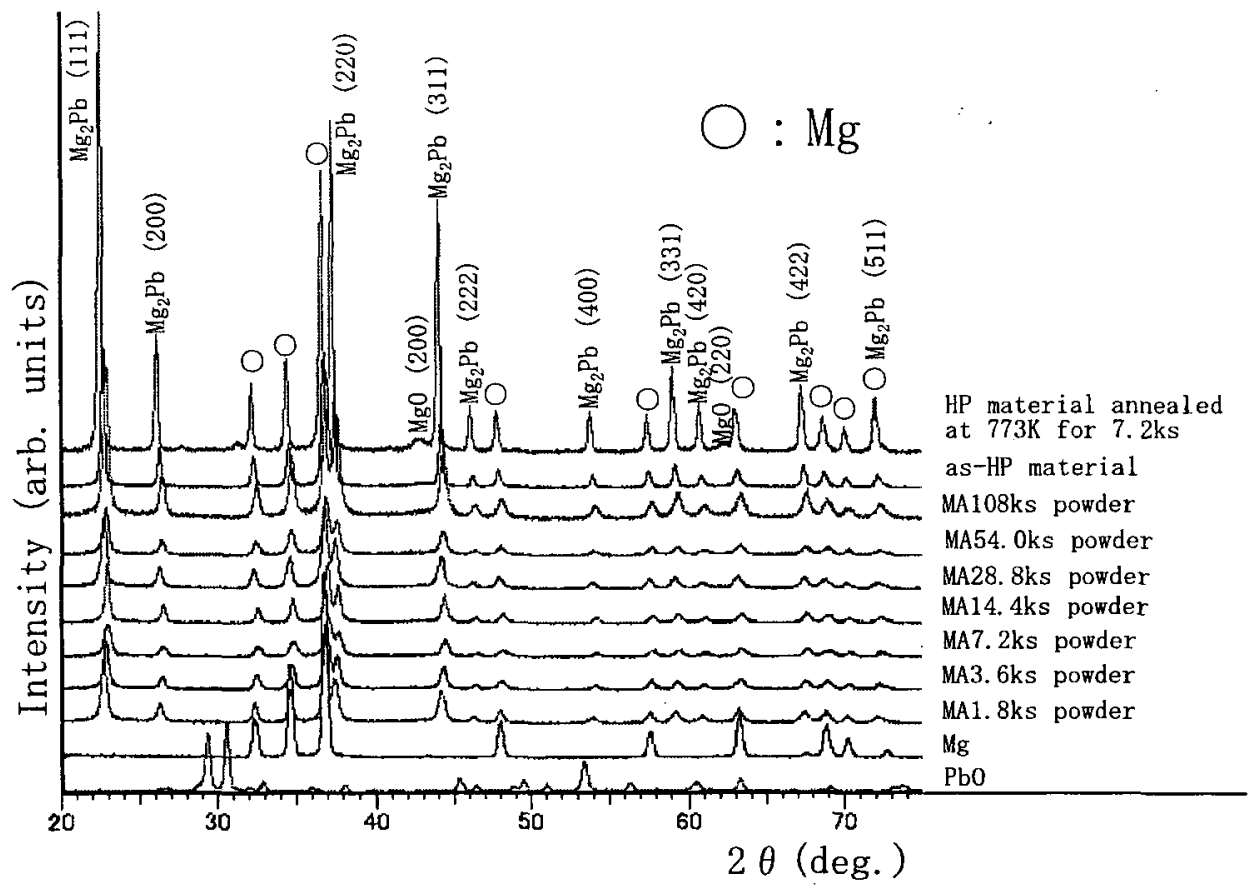

Fig.3 X-ray diffraction patterns of MA powders and HP material of Mg-PbO system.

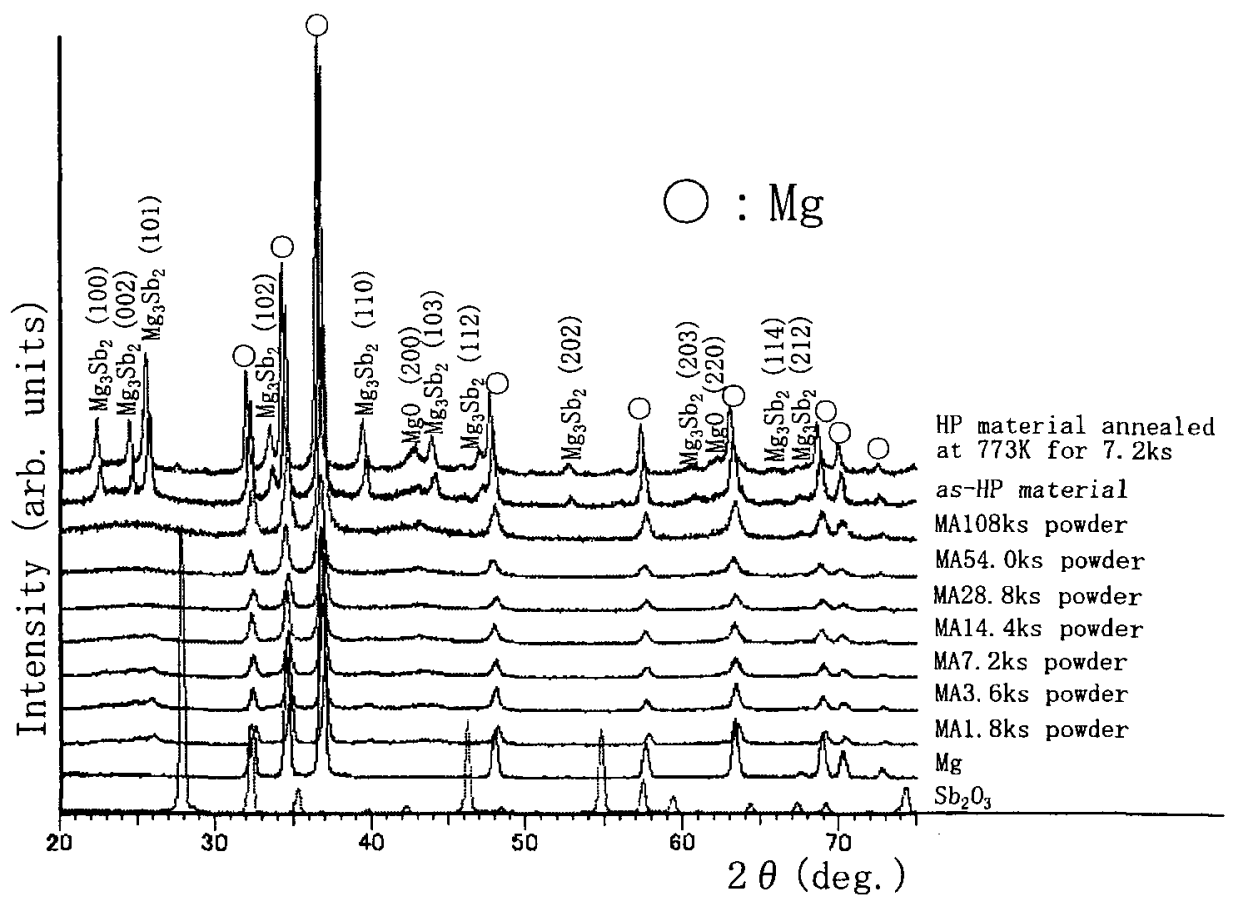

Fig.4 X-ray diffraction patterns of MA powders and $\mathrm{HP}$ material of $\mathrm{Mg}-\mathrm{Sb}_{2} \mathrm{O}_{3}$ system. 
きなかった，しかし，HP体作製時の加熱掞よびその後の加熱 により $\mathrm{Mg}_{3} \mathrm{Sb}_{2}$ および $\mathrm{MgO}$ からの明嘹な回折線が検出できる ようになった。

以上の固相反応はFig.5に示した酸化物の標準生成自由エネ ルギーのによる駆動力だけでなく，Table 2 に示した金属間化 合物も含めた反応の駆動力 ${ }^{6,7)}$ に基づくものである。これは 反応式の左辺から右辺への反応の駆動エネルギー(298 K)であ るが，非常に大きな駆動力であることが分かり，MAにより， さらなるエネルギーが導入され，比較的呧温で反応が起こっ

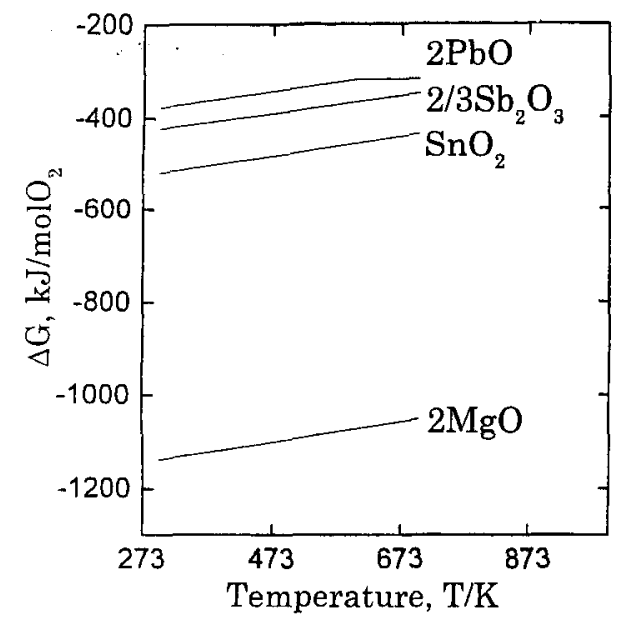

Fig.5 The standard free energies of formation of oxides as a function of temperature.

Table 2 The driving force of displacement reactions.

\begin{tabular}{|c|c|c|}
\hline \multirow{2}{*}{ reaction } & \multicolumn{2}{|c|}{$\Delta G^{\circ}$ at $298 \mathrm{~K}$} \\
\hline & kJ & $\mathrm{kJ} / \mathrm{molMgO}$ \\
\hline $4 \mathrm{Mg}+\mathrm{SnO}_{2} \rightarrow 2 \mathrm{MgO}+\mathrm{Mg}_{2} \mathrm{Sn}$ & -712 & -356 \\
\hline $3 \mathrm{Mg}+\mathrm{PbO} \rightarrow \mathrm{MgO}+\mathrm{Mg}_{2} \mathrm{~Pb}$ & -425 & -425 \\
\hline $6 \mathrm{Mg}+\mathrm{Sb}_{2} \mathrm{O}_{3} \rightarrow 3 \mathrm{MgO}+\mathrm{Mg}_{3} \mathrm{Sb}_{2}$ & -1355 & -452 \\
\hline
\end{tabular}

たことが賽える．MA 中の固相反応で注目すべきは金属間化 合物からの回折線の存在である. $\mathrm{Mg}-\mathrm{SnO}_{2}$ 系および $\mathrm{Mg}-\mathrm{PbO}$ 系ではMAの進行に伴い回折線強度が増大し, 生成量が増加 していくことが分かる.

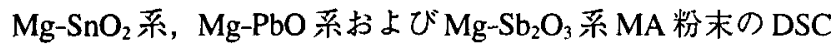
熱分析結果を Fig.6 (a), (b) および(c)に示す．Fig.6(a)の Mg$\mathrm{SnO}_{2}$ 系 DSC 曲線より $473 \mathrm{~K}$ 近傍に発熱ピークが得られ，MA 時間 $28.8 \mathrm{ks}$ 以上で, この発熱ピークが消失していることが, $\mathrm{X}$ 線回折で得られた $\mathrm{SnO}_{2}$ のピークの消失 (Fig.2) に対応してい る. 従って, $473 \mathrm{~K}$ 近傍の発熱ピークは $\mathrm{SnO}_{2}$ の分解に付随し たピークであることが分かる，一方，MA3.6ks の粉末を $573 \mathrm{~K}$

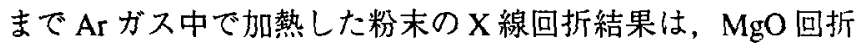
ピークの回折線強度が増大したかの判定は不可能であったが $\mathrm{Mg}_{2} \mathrm{Sn}$ の回折ピークの回折線強度增加という変化をもたらし た.しかし，発熱ピークのないMA28.8 ks の粉末を同様に加 熱した粉末では加熱により結晶粒サイズが増大した結果, $\mathrm{Mg}$ の回折ピークの幅が隇少するのみで $\mathrm{Mg}_{2} \mathrm{Sn}$ 等の回折線強度の 増加は認められなかった。従って, Fig.6(a)の673K〜773Kの 発熟ピークは酸素の置換反応に伴う $\mathrm{Mg}_{2} \mathrm{Sn}$ および $\mathrm{MgO}$ の生成 の発熱ピークであると推定される。すすなわち MAにより, 熱 力学的に不安定な添加酸化物 $\mathrm{SnO}_{2}$ がまず分解し，次に遊離し た $\mathrm{Sn}$ および $\mathrm{O}$ (酸素)が $\mathrm{Mg}$ と反応し， $\mathrm{Mg}_{2} \mathrm{Sn}$ および $\mathrm{MgO}$ が 生成する.これが $673 \mathrm{~K} \sim 773 \mathrm{~K}$ の発熱ピークに対応すると判 断される. しかし Fig.6(b)の Mg-PbO系抢よび(c)の Mg-Sb2 $\mathrm{O}_{3}$ 系のDSC曲線ではミリング時間の变化に基づく著しいピーク

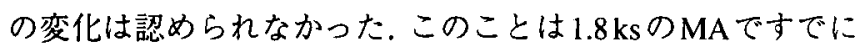
添加酸化物加の回折線が消失しているXRD結果と対応して おり, 添加酸化物の分解に伴う低温側の発熱ピークは現れて いない. 従って, $\mathrm{Mg}-\mathrm{PbO}$ 系, $\mathrm{Mg}-\mathrm{Sb}_{2} \mathrm{O}_{3}$ 系では $\mathrm{MgO}$ など金属 間化合物の生成による発熱ピークのみが $673 \mathrm{~K} 〜 773 \mathrm{~K} に$ 現れ ている. $\mathrm{SnO}_{2}$ のみが $7.2 \mathrm{ks}$ の $\mathrm{MA}$ 時間まで残存していること は他の系に比べて $1 \mathrm{~mol}$ あたりの $\mathrm{MgO}$ 生成のために必要な反 応の駆動力が低い(Table 2)ためと思われる.
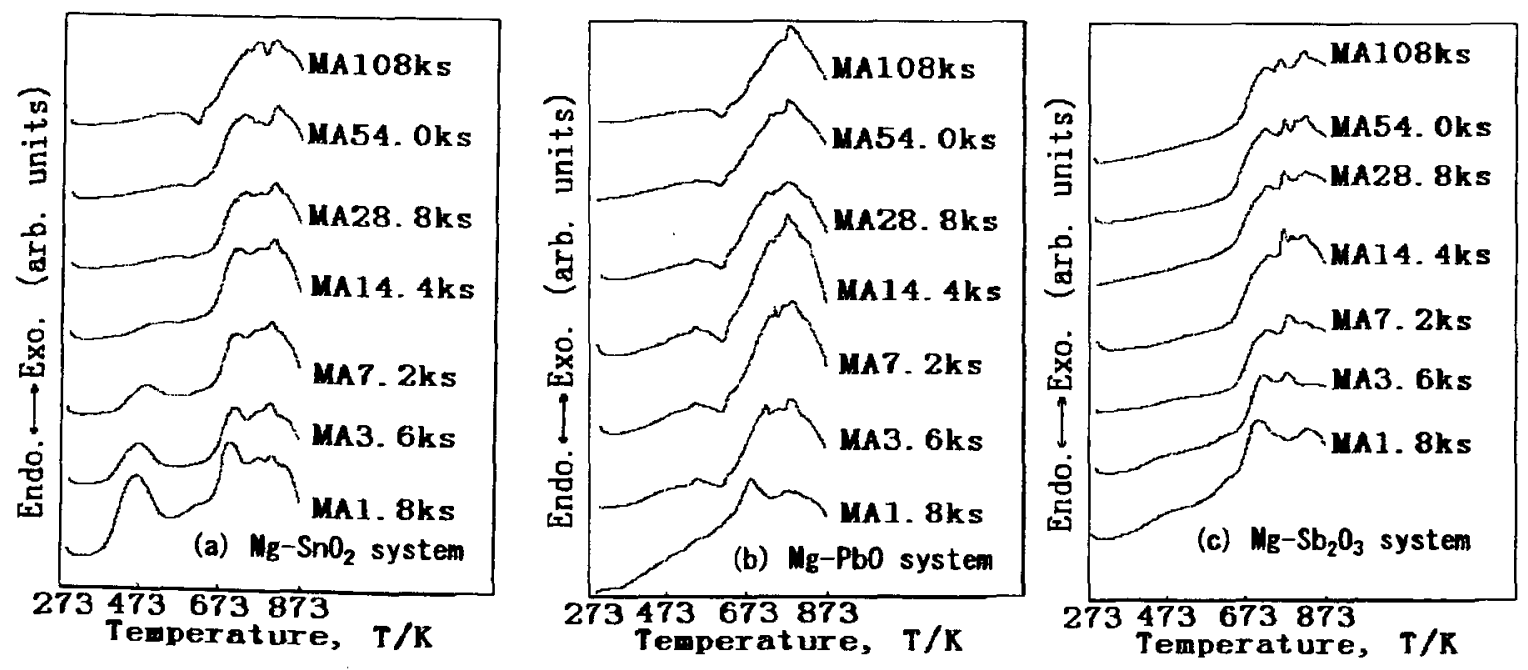

Fig.6 DSC curves of MA powders at various milling times; (a) $\mathrm{Mg}-\mathrm{SnO}_{2}$ system, (b) $\mathrm{Mg}-\mathrm{PbO}$ system and (c) $\mathrm{Mg}-\mathrm{Sb}_{2} \mathrm{O}_{3}$ system. 


\subsection{MA 粉末の硬さ}

MA 時間の増加に対するMA 粉末の硬さの変化を Fig.7に示 す。全ての系において MAを行うことにより，硬さは急激に 上界しHV140にまで達し，その後は䋸やかに増加してHV150 以上にまで達した。これは MAにより酸化物粒子の微細分散 が図られ，そこに塑性ひずみが導入されて転位密度が上昇し たため MA 初期段階で急激に硬さが上昇したと思われる。や がて MA 時の摩擦熱などにより動的回復も起こり微細な転位 セル構造が形成され，さらにセル壁の転位密度の増加ととも に粒界方位差が増大してナノ結晶組織が形成され ，それとと もに硬さの増加が飽和状態に達したと推定される。

$3.3 \mathrm{HP}$ 体の硬さ

HP 体の硬さを Fig.8に示す. Fig.8 中の硬さは空気炉中で各温 度での加熱を $7.2 \mathrm{ks}$ 行い, その後, 室温まで空冷し, 室温で硬さ を測定した值である．全ての系においてHPまま材ではHV90 程度の硬さを示し, MA108 ks 行った粉末よりも HV70程度の 硬さの低下が見られた。これはHP体作製時の加熱によりMAに
より導入された加工硬化の回復が起こったためであると推測 できる．また，HP後の 573K までの加熱では硬さの大きな低下 は認められず，HV85以上の硬さを維持できた。 そこで573Kで

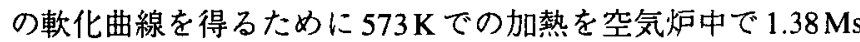
(384h) まで行い，室温で硬さを測定した結果を Fig.9に示す. 長時間の加熱による著しい軟化は認められずHV75以上の硬さを 維持し続けた。また，573Kで約 $1.38 \mathrm{Ms}$ まで加熱した試料に $\mathrm{X}$ 線回折を行った結果，金属間化合物 $\left(\mathrm{Mg}_{2} \mathrm{Sn}\right.$ など) $/ \mathrm{Mg}$ (共に 相対強度 100 の回折線を使用) の回折線強度比は HPまま材の それと比べてほとんど変化がなく，773Kで $7.2 \mathrm{ks}$ 加熱した試料 での回折線 (Fig.2) に比べて強度比が低く，回折線の幅が拡がり を持っていた：これは $673 \mathrm{~K} て ゙ \mathrm{HP}$ を行った材料を $573 \mathrm{~K} て ゙$ 加熱 しても組織变化は起こりにくいことを示している，一方， $673 \mathrm{~K}$ での加熱により硬さの大きな低下が起こったのは (Fig.8), 七 ルと金属間化合物の粗大化が起こったためと推察できる.

$3.4 \mathrm{HP}$ 体の組織

Fig. 10 に $\mathrm{Mg}-\mathrm{SnO}_{2}$ 系 HP まま材の TEM 組織写真を示す。

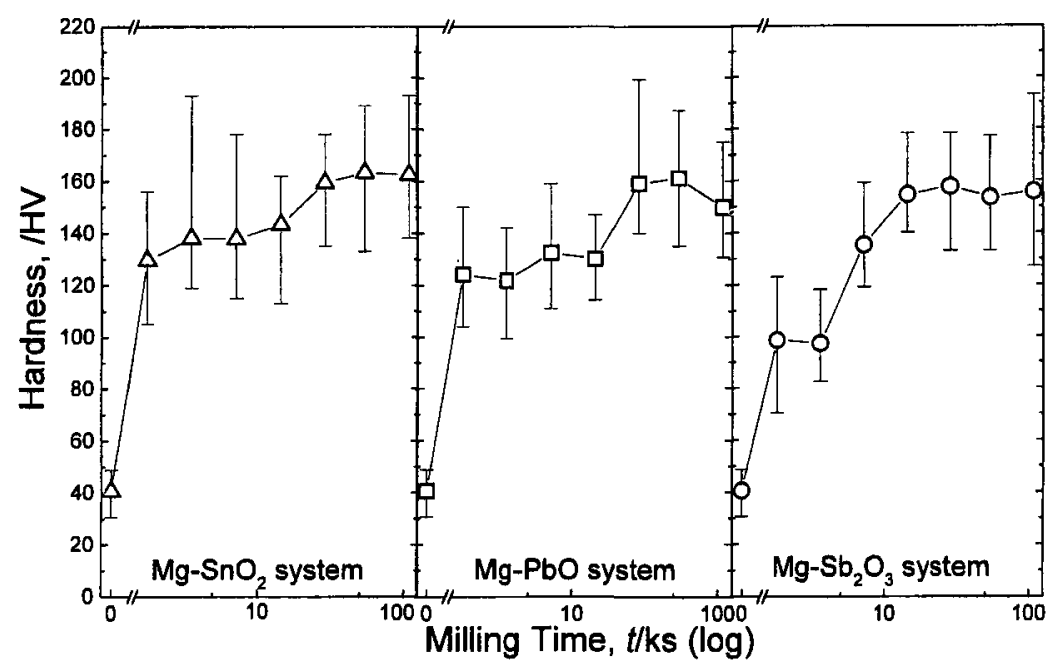

Fig.7 Hardness of MA powders as a function of milling time.

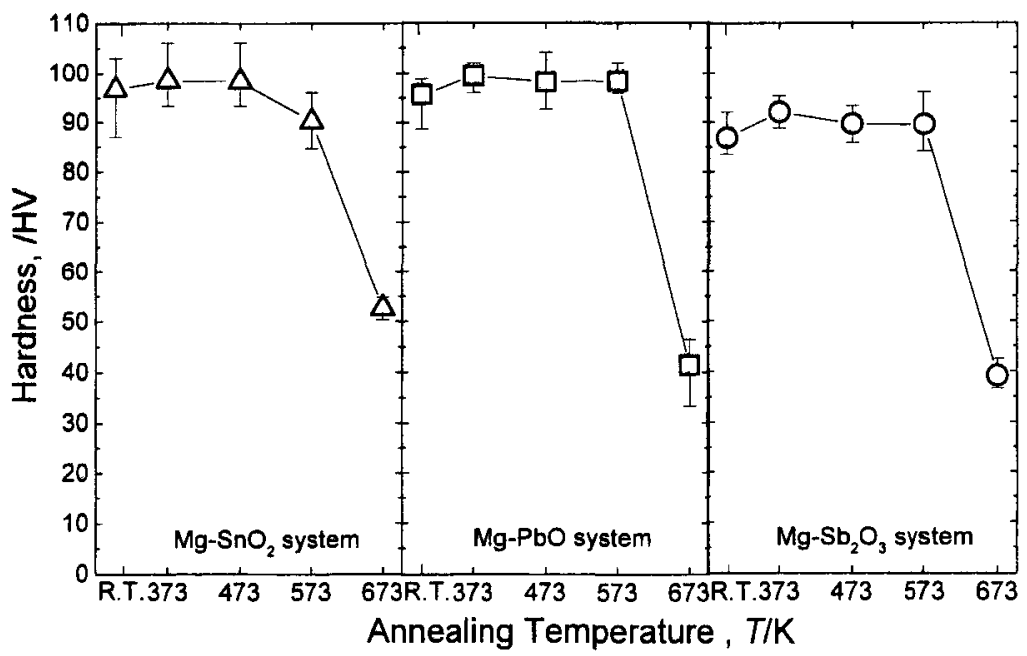

Fig.8 Changes in hardness of HP materials on isochronal heating for $7.2 \mathrm{ks}$ at various temperatures. 


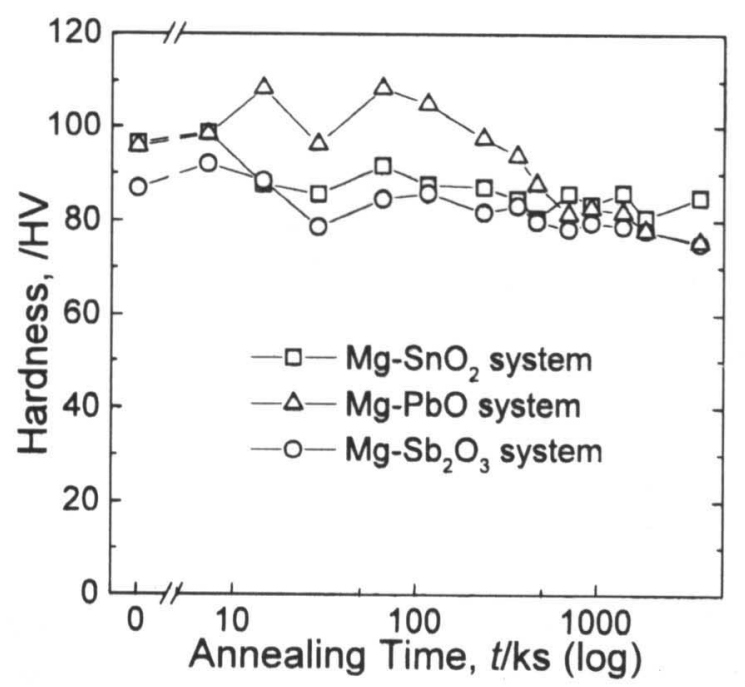

Fig.9 Changes in hardness of HP materials annealed at $573 \mathrm{~K}$.

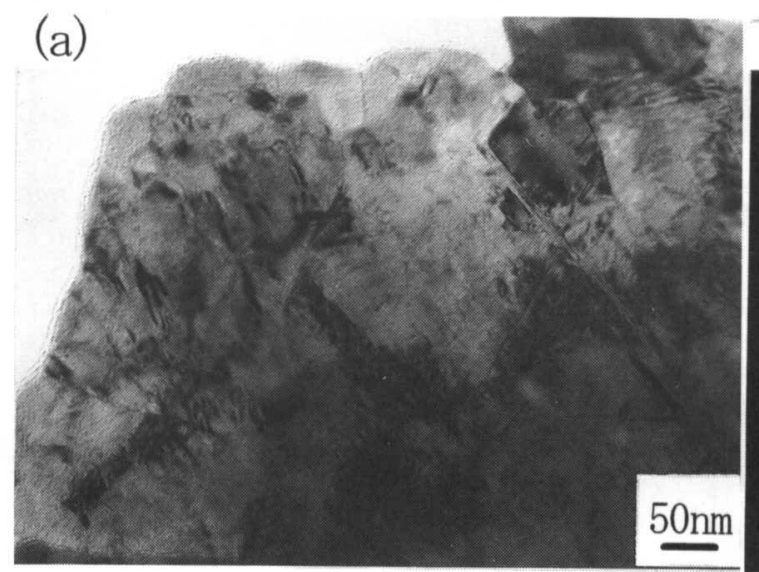

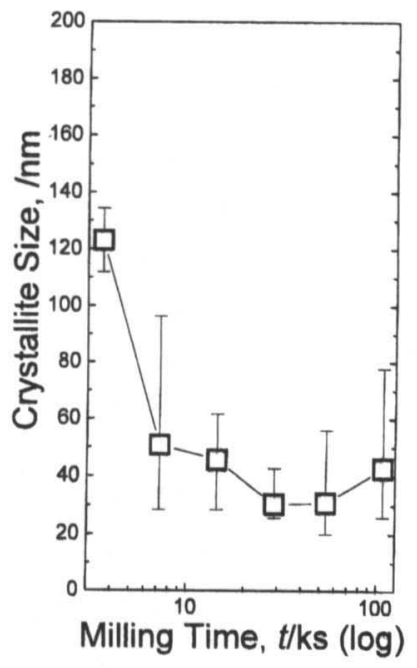

Fig.11 Crystallite size of MA powders of $\mathrm{Mg}_{-} \mathrm{Sb}_{2} \mathrm{O}_{3}$ system as a function of milling time.

Fig.10 Transmission electron micrographs of as- $\mathrm{HP}$ material of $\mathrm{Mg}_{-} \mathrm{SnO}_{2}$ system; (a) bright field image and (b) diffraction pattern taken from the observed area.

Fig.10(a)は明視野像であり, Fig.10(b)はFig.10(a)の視野とほ ほ同等の視野から得られた電子回折パターンである.この電 子回折パターンの指数付けは, 試料が $\mathrm{Mg}, \mathrm{MgO}$ および $\mathrm{Mg}_{2} \mathrm{Sn}$ により構成されていると考えて, 行った. HP時の加熱により ひずみの回復が起こっており, 転位密度の高い領域は認めら れないが, Fig.10(a)に認められるように微細結晶粒組織 (粒径: $300 \mathrm{~nm}$ 以下) を示した. ここで, 一例として $\mathrm{Mg}_{-} \mathrm{Sb}_{2} \mathrm{O}_{3}$ 系 $\mathrm{MA}$ 粉末の X 線回折結果 (Fig.4) から Mg の回折角度と回折ピーク の半価幅を求めて, (1)式のScherrerの式に基づいて求めた結 晶粒サイズを MA 時間の变化に対して Fig.11に示す. Mgの 各々の回折ピークについて求めた結晶粒サイズの測定值の範 囲をエラーバーで示しており, その平均値の変化を示してい る.なお, 半価幅は実測した半価幅 $\left(\mathrm{B}_{\mathrm{exp}}\right)$ をそのまま用いず, 十分焼鈍した純 $\mathrm{Mg}$ 粉末の半価幅 $\left(\mathrm{B}_{\text {inst }}\right)$ を用いて, (2)式により 補正した半価幅 $\left(\mathrm{B}_{\text {sample }}\right)$ を用いた.

$$
t=\frac{0.9 \lambda}{\mathrm{B}_{\text {sample }} \cos \theta}
$$

ただし, $t:$ 結晶粒サイズ, $\lambda:$ 入射 X線の波長, $\mathrm{B}:$ 半価幅, $\theta$ : Bragg 角

$$
\mathrm{B}_{\text {sample }}^{2}=\mathrm{B}_{\text {exp }}^{2}-\mathrm{B}_{\text {inst }}^{2}
$$

他の二つの系でもほぼ同様の結果が得られたが, MA 時間の 増加につれて結晶粒サイズが減少し, 約 $40 \mathrm{~nm}$ の結晶粒サイ ズまで組織の微細化が起こった。この MA 粉末の結晶粒サイ ズに比べて, HPまま材ではHP時の加熱によって, 結晶粒成 長が起こったことが分かる．しかし Fig.10(b)ではリングパ ターンを示すなどHPまま材では, なおサブミクロンの微細な 結晶粒組織であり, $\mathrm{MgO}$ 等の微細分散によるピン止め効果の ためにHP時の加熱による粒成長が抑制されたことが窥える.

\section{4 ま と}

$\mathrm{Mg}$ 粉末に低融点金属の酸化物 $\left(\mathrm{SnO}_{2}, \mathrm{PbO}, \mathrm{Sb}_{2} \mathrm{O}_{3}\right)$ 粉末を添 加しMA処理を行い, MA108ks行った粉末をもとに真空ホッ トプレスにより HP体を作製した. 固相反応による Mg と低融 
点金属との合金化の過程，および低融点金属の酸化物を加え たことによる硬さの変化を調べ，以下の知見を得た。

(1) MA 中およびその後の加熱で, Mgマトリックス中に分散 した酸化物 $\left(\mathrm{SnO}_{2}, \mathrm{PbO}, \mathrm{Sb}_{2} \mathrm{O}_{3}\right)$ 粒子が分解して，金属間化 合物 $\left(\mathrm{Mg}_{2} \mathrm{Sn}, \mathrm{Mg}_{2} \mathrm{~Pb}, \mathrm{Mg}_{3} \mathrm{Sb}_{2}\right)$ と $\mathrm{MgO}$ の生成が認められた。

(2) $\mathrm{Mg}_{-} \mathrm{SnO}_{2}$ 系および $\mathrm{Mg}-\mathrm{PbO}$ 系では $\mathrm{MA}$ 処理中に $\mathrm{Mg}_{2} \mathrm{Sn}$ およ び $\mathrm{Mg}_{2} \mathrm{~Pb}$ が生成しはじめたが, $\mathrm{Mg}_{-} \mathrm{Sb}_{2} \mathrm{O}_{3}$ 系では $\mathrm{MA}$ 中に は $\mathrm{Mg}_{3} \mathrm{Sb}_{2}$ の生成は起こらなかった。

(3) MA 時間の増加とともにMA 粉末の硬さは増加し, MA 初 期では急激に硬さが増加したが，その後のMAでは硬さは 緩やかに増加し，HV150以上にまで達した。

（4）HPまま材ではMA粉末に比べてHV70ほど低下したが, 約

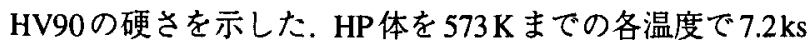
の加熱を行ったところ硬さの低下は見られなかったが, $673 \mathrm{~K}$ での $7.2 \mathrm{ks}$ の加熱で軟化が起こった。

(5) 全ての系において，MA粉末では約 $40 \mathrm{~nm}$ の結晶粒サイズ を示した.HPまま材ではHP時の加熱により回復および再 結晶が起こったが，粒径が $300 \mathrm{~nm}$ 以下の微細結晶粒組織 が得られた。

\section{謝辞}

おわりに，本実験に卒業研究生として協力された大野泰嗣 および河西真人両氏に深く感謝する．本実験に助言を頂いた
久保田正広助手に深謝の意を表する。

\section{文献}

1) 市川理衛, 谷川隆俊: "鋳造マグネシウム合金の内部減衰能 におよぼす合金成分の影響",軽金属, 12(1962)135-140.

2）諸住正太郎, 菊地迪夫, 幸田成康: "マグネシウム合金粉末 押出し材の機械的性質 ", 軽金属, 15(1965)55-64.

3）久恒中陽, 西成基: "マグネシウムを主とするアルミニウム 一錫ーマグネシウム合金の時効について", 軽金属, 12 (1954)111-117.

4) 山崎晃弘, 金子純一,菅又信:"メカニカルアロイング法に よる $\mathrm{Mg}-\mathrm{SiO}_{2}$ 系の固相反応", 粉体および粉末治金, 48 (2001)61-66.

5) Y.Guangyin, S.Yangshan and D.Wenjiang: "Effects of Sb Addition on the Microstructure and Mechanical Properties of AZ91 Magnesium Alloy", Scripta Mater, 43(2000)1009-1013.

6) I.Barin: Thermochemical Data of Pure Substances, VCH, New York, (1989).

7) O.Kubaschewski, C.B.Alcock and P.J.Spencer: "Materials Thermochemistry, 6 $6_{\text {th }}$ Edition", Pergamon Press, (1993).

8) H.J.Fecht, E.Hellestern, Z.Fu and W.L.Johnson: "Nanocrystalline Metals Prepared by High-Energy Ball Milling", Metal. Trans., 21A(1990)2333-2337. 